and pancreatin 0.25 gram, and digesting at a temp. of $r \circ 4^{\circ} \mathrm{F}$. until one cc. of the digested fluid mixed with forty cc. water upon the addition of one cc. nitric acid conc. no longer gave any precipitate, within five minutes after addition of the acid.

\begin{tabular}{|c|c|c|c|c|c|c|c|c|}
\hline $\begin{array}{c}\text { Pancreatin } \\
\text { macerated } \\
\text { in acid. } \\
\text { Per cent. }\end{array}$ & $\begin{array}{l}\text { Albumin } \\
\text { test com- } \\
\text { pletely } \\
\text { digested } \\
\text { in hrs. }\end{array}$ & $\begin{array}{l}1 \mathrm{hr} . \\
\text { Hrs. }\end{array}$ & $\begin{array}{c}4 \text { hrs. } \\
\text { Hrs. }\end{array}$ & $\begin{array}{c}24 \text { brs. } \\
\text { Hrs. }\end{array}$ & $\begin{array}{c}7 \text { days. } \\
\text { Hrs. }\end{array}$ & $\begin{array}{c}15 \text { dass } \\
\text { Hrs. }\end{array}$ & $\begin{array}{l}4 \text { wks. } \\
\text { Hrs. }\end{array}$ & $\begin{array}{c}10 \text { wks } \\
\text { Hrs. }\end{array}$ \\
\hline 0.05 & $13 / 4$ & . & $\ldots$ & $13 / 4$ & $\ldots$ & . & $15 / 4$ & $\ldots$ \\
\hline 0.15 & $1^{3 / 4}$ & . & $\ldots$ & $13 / 4$ & 2 & . & $13 / 4$ & $\ldots$ \\
\hline 0.25 & $13 /$ & . & $\ldots$ & $13 / 4$ & $2^{1 / 2}$ & . & $13 / 4$ & 3 \\
\hline 0.30 & $13 / 4$ & . & $\ldots$ & $4^{1 / 2}$ & $\ldots$ & 4 & $2^{1 / 4}$ & 3 \\
\hline 0.35 & $13 / 4$ & 3 & $3 / 4$ & $51 / 2$ & 6 & 5 & $31 / 2$ & $31 / 2$ \\
\hline
\end{tabular}

Destructive Action of Acids and Alkalies upon the Amylopsin of THE PANCREATIN IN WATER SOLUTION.

Acetic acid 8.00 per cent........... $100 \mathrm{cc}$.

Pancreatir...................21/2 grams

$1 / 2$ hour at $70^{\circ} \mathrm{F}$. Amylopsin completely destroyed

$1 / 2$ hour at $100^{\circ} \mathrm{F}$. Amylopsin completely destroyed

Hydrochloric acid 0.038 per cent. absolute $100 \mathrm{cc}$.

Pancreatin.................... $2^{1 / 2}$ grams

$1 / 2$ hour at $100^{\circ} \mathrm{F}$. Required 4 hours for L. S. P. test

1 hour at $100^{\circ} \mathrm{F}$. Required 12 hours for $U$. S. P. test

24 hours at $70^{\circ} \mathrm{F}$, Destroyed in 24 hours

Hydrochloric acid 0.095 per cent. absolute $100 \mathrm{cc}$

Pancreatin................... $2^{1 / 2}$ grams

$1 / 2$ hour at $70^{\circ} \mathrm{F}$. Retained full activity

1 hour at $70^{\circ} \mathrm{F}$. Retained full activity

2 hour at $100^{\circ} \mathrm{F}$. Completely destroyed

1 hour at $100^{\circ} \mathrm{F}$. Completely destroyed

Hydrochloric acid 0.127 per cent. absolute $100 \mathrm{cc}$

Pancreatin.................. 21/2 grams

1/2 hour at $70^{\circ} \mathrm{F}$. Nearly destroyed. Does not stand

C. S. P. test after 24 hours

$1 / 2$ hour at $100^{\circ} \mathrm{F}$. Completely destroyed

Hydrochloric acid 0.38 per cent. absolute $100 \mathrm{cc}$

Pancreatin................... $21 / 2$ grams

20 minutes at $70^{\circ} \mathrm{F}$. Completely destroyed

Hydrochloric acid 1.90 per cent, absolute $100 \mathrm{cc}$.

Pancreatin................... 21/2 grams Destroyed in 2 minutes

Sodium carbonate anhycrous. . . . . . . 0.05 gram Water........................ $100 \mathrm{cc}$

Pancreatin..................

1 hour at $70^{\circ} \mathrm{F} \quad$ Retained full activity

1 hour at $100^{\circ} \mathrm{F}, \quad$ Required $1 / 2$ hour for U. S. P. test

Sodium carbonate anhydrous......... 0.125 gram Water...................... $100 \mathrm{cc}$

Pancreatin.................. $2^{1 / 2}$ grams

$1 / 2$ hour at $100^{\circ}$ F. Required $1 / 2$ hour for U. S. P. test

1 hour at $110^{\circ} \mathrm{F}$. Required $1 / / 2$ hours for U. S. P. test

1 hour at $70^{\circ} \mathrm{F}$. Required 20 minutes for U. S. P. test

Sodium carbonate anhydrous......... 0.25 gram

Water....................... $100 \mathrm{cc}$

Pancreatin...................

1 hour at $70^{\circ} \mathrm{F}$. Required 3,4 hour for U. S. P. test

1 hour at $100^{\circ} \mathrm{F}$. Completely destroyed

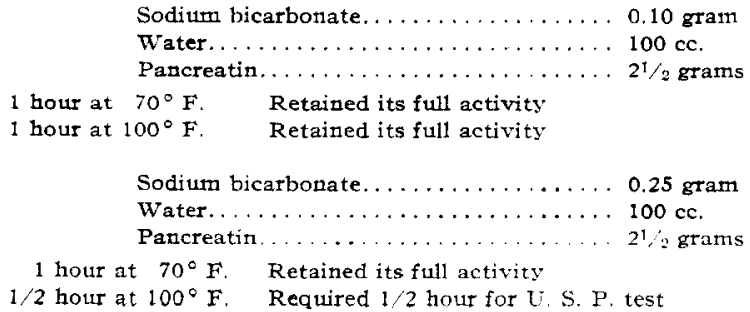

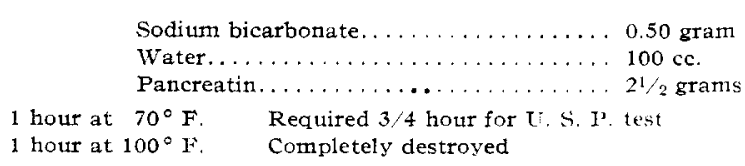

Sodium bicarbonate. . . . . . . . . . 21/2 gram Water..................... $20 \mathrm{cc}$.

Pancreatin.................. $71 / 2$ grams Kept at $100^{\circ} \mathrm{F}$. for 24 hours Amylopsin completely destroyed Trypsin activity reduced a half

Caustic soda $N / 1$ solution. . . . . . . $3 \mathrm{cc}$

Water..................... $17 \mathrm{cc}$

Pancreatin................ 0.25 gran

Destroyed trypsin and anylopsin in 15 minutes at $104^{\circ} \mathrm{F}$.

Hydrochloric acid 0.05 per cent. . . $25 \mathrm{cc}$

Pancreatin................. 2 grams

24 hours at $70^{\circ} \mathrm{F}$. Required $4 \frac{1}{2}$ hours to stand $t . s$. P. test BROOKLYN, N. Y.,

November, 1910.

\section{THE ASH CONTENT OF CAPSICUM.}

BY HARRY E. SINDALL.

Received July 25, 1911.

Since the Food and Drugs Act has become a law, Circular No. I9, Office of the Secretary of Agriculture, on the Standards of Purity for Food Products, previously published, has received an added interest and importance, since it serves as a guide to the officials in charge of the enforcement of the law, as well as to the manufactures of food products. In view of this fact, and in fairness to all concerned, it is important that these standards be stringent enough to exclude wilful adulteration or careless manufacture, and still not be too exacting to discriminate against pure products. Standards for manufactured articles are necessarily more or less arbitrary, as they must be based on honest commercial practice and custom, but standards for natural products are based on the analysis made of a great number of samples of the article in question, the more the better. The author does not intend to criticize these standards, for, as a whole, they seem fair and just, but in some instances they seem hardly possible of attainment with the natural products in the market to-day. The spice grinders in particular have had many difficulties with the total and acid-insoluble ash of capsicum or red pepper. In order to establish fair standards, it is important that all available data on undoubtedly pure samples should be published, and with this in view, the writer contributes the data tabulated below.

The first five tables represent samples of large lots of capsicum, cleaned and ground in the factory, under the personal supervision of the writer, arranged by years to show annual variations. These samples are composites taken at frequent intervals during grinding, and each one represents, as near as possible, the composition of about five hundred pounds of ground capsicum. The peppers in the first four tables contained practically no stems, while Table $V$ is self-explanatory in this respect. The American Cayenne of Table VI was not sifted before grinding, to the knowledge of the author. In addition to the above are given analyses of ground capsicum pur- 
chased in open market during the present year. Although the writer cannot vouch for the care taken in cleaning the pods before grinding, it may be said that these samples represent reputable houses only, and show the character of the better grade of ground capsicum on the Eastern market to-day. As a matter of interest are included a few analyses to show the nature of the refuse which is sifted from the pods in the millroom before grinding. The A. O. A. C. methods of analysis were used.

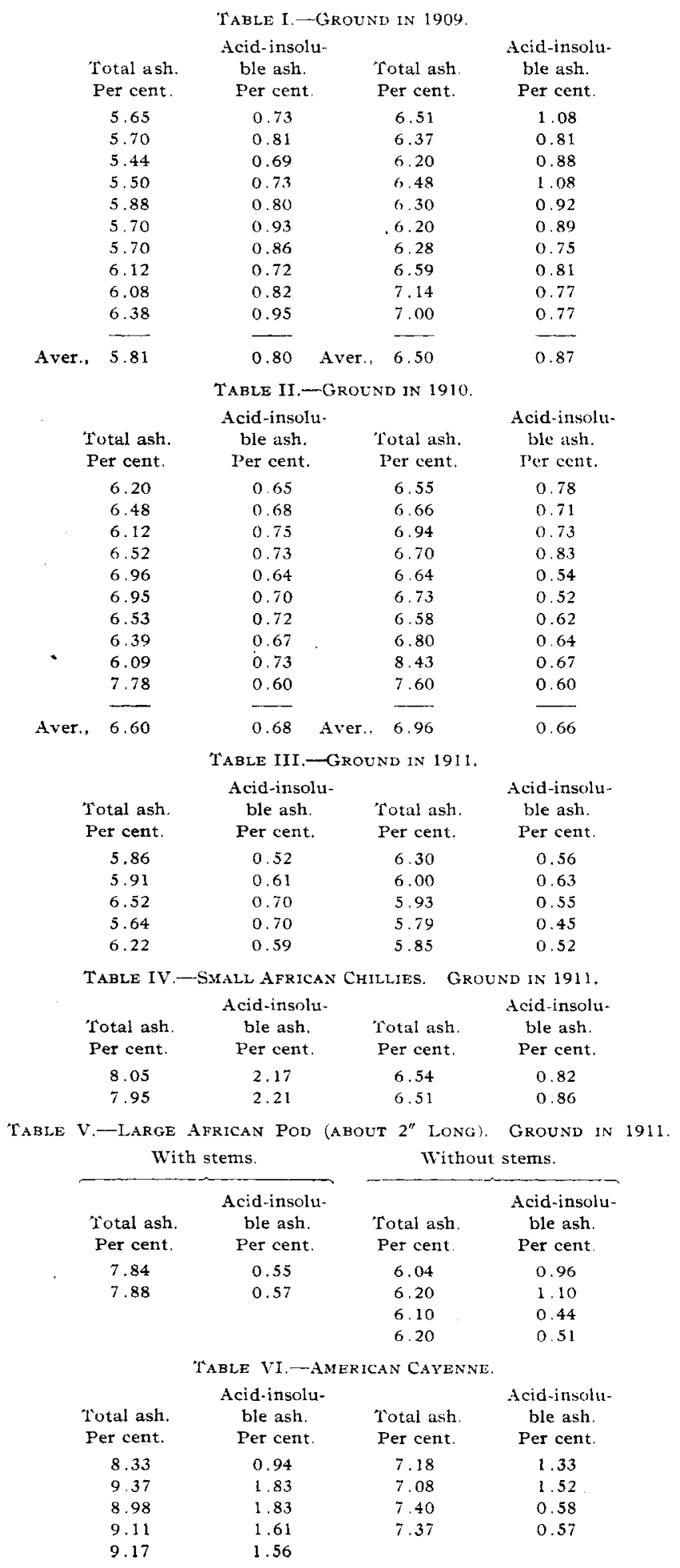

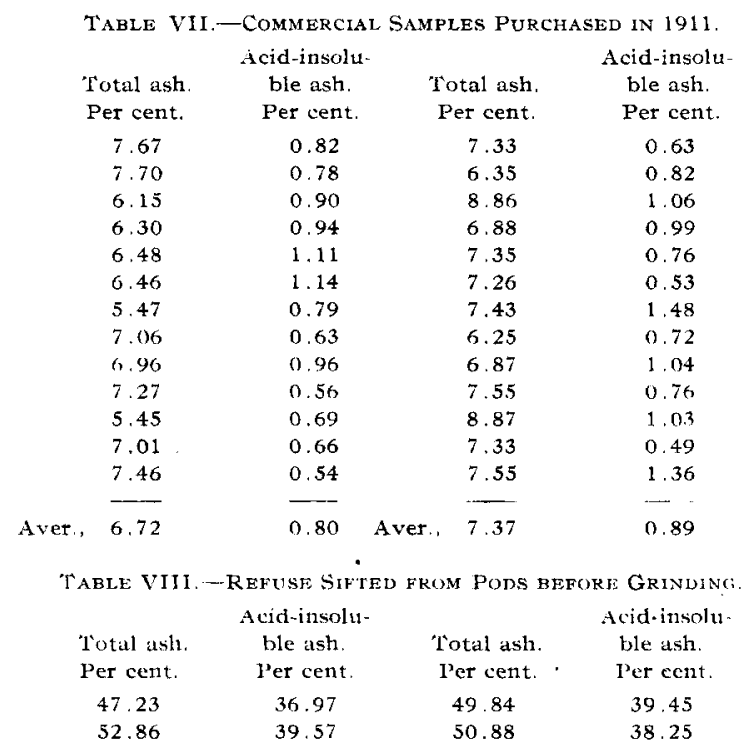

Circular No. Ig allows a maximum total ash of 6.5 per cent. and 0.5 per cent. acid-insoluble ash. The first three tables show the impossibility of keeping down to these limits, even when grinding the best grades of pods and cleaning as thoroughly as possible. The total ash requirement would exclude many pure samples, and practically none of them can be brought down to the limit of acid-insoluble ash. The tables also show that a variation may occur in the run of capsicum in different seasons. Also, as might be expected, high total ash is not necessarily caused by high acid-insoluble ash. In other words, acid-insoluble ash, being mostly in the form of adherent sand, is independent of the natural ash of the pod.

Considering the above data, taken in connection with several years' experience with this spice, it would appear that the Standards for total ash and acid-insoluble ash should be raised to 7 per cent. and 1 per cent., respectively. This can generally be obtained by careful factory practice, and would exclude dirty and carelessly ground capsicum. ${ }^{\mathrm{I}}$ The official Swiss standard for capsicum are 6.5 per cent. total ash and I per cent. insoluble ash. It should be remembered, in this connection, that capsicum or any other spice should not be condemned by the analysis of one package, as all practical spice grinders know that a large stone may get into the mill, in spite of careful cleaning. At least four packages should be analyzed separately.

laboratory Weikel \& Smith Spice Co., Philadelphia, Pa

\section{ESTIMATION OF MORPHINE BY EXTRACTION WITH PHENYL-ETHYL ALCOHOL:"}

By. A. D. 'HORBUR.

Received July 5, 1911

Phenylethyl alcohol dissolves a little more than one-twentieth its weight of crystallized morphine

${ }^{1}$ Schweiz Lebunsmittelbuck, 2nd Ed., p. 197. Society.

2 Read before the Pharmaceutical Section of the American Chemical 